Utah State University

DigitalCommons@USU

Fall 1957

\title{
The Effect of Prior Location on Alfalfa Foraging by Honey Bees
}

M. D. Levin

George E. Bohart

Utah State University

Follow this and additional works at: https://digitalcommons.usu.edu/piru_pubs

Part of the Entomology Commons

\section{Recommended Citation}

Levin, M. D., and G. E. Bohart. 1957. The Effect of Prior Location on Alfalfa Foraging by Honey Bees. Jour. Ec. Ent. 50(5): 629-632, October 1957.

This Article is brought to you for free and open access by the Pollinating Insects Research Unit at DigitalCommons@USU. It has been accepted for inclusion in All PIRU Publications by an authorized administrator of DigitalCommons@USU. For more information, please contact digitalcommons@usu.edu.

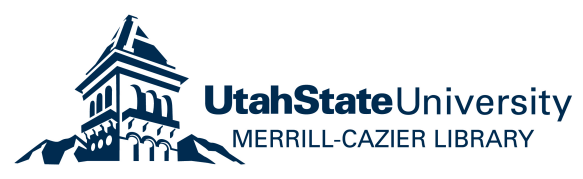




\title{
The Effect of Prior Location on Alfalfa Foraging by Honey Bees ${ }^{1}$
}

\author{
M. D. Leviv and G. E. Bohart, Entomology Research Division, Agr. Res. Serv., U.S.D.A., ${ }^{2,3}$
}

A successful method of increasing the collection of alfalfa nectar and pollen (especially the latter) by honey bees, Apis mellifera L., from colonies placed in or near alfalfa fields would be of great value in pollination. In some alfalfa-seed areas beekeepers shuttle colonies back and forth from one field to another. This practice is based on the belief that after disorientation bees will concentrate on the nearest available forage. To test the value of various types of colony movements in the management of honey bees for alfalfa pollination, we conducted a series of experiments in northern Utah from 1953 to 1955.

Methods.-In each of three experiments three groups of colonies were used. One group had been placed in an alfalfa field near the beginning of bloom, the second was moved into the same field from an area where an abundance of bloom was available to the bees, and the third was moved into the field from a mountain location where alfalfa was not available and the bees presumably had no experience with alfalfa. Collection of data started the day after the second and third groups were moved into the field.

Two types of data were collected. (1) Pollen traps were placed under three to five hives in each group and samples of pollen were collected daily from each trap, and the amount of alfalfa pollen in the daily collections was determined. (2) Samples of 50 to 100 foraging bees were taken daily from the entrances of three to five other hives in each group, and examined to determine the presence of alfalfa pollen in the proboscis fossa, as described by Levin (1955) and Vansell (1955).

In each experiment an effort was made to select colonies of about equal strength. In 1955 the amounts of brood and pollen in each colony were measured to help explain differences in total amounts of pollen gathered.

Locations.-The experiments were conducted during July of 1953 and 1954 and July and August of 1955. In 1953 the alfalfa field to which the colonies were moved was on the Evans Farm, 3 miles south of Logan. About 10 acres of seed alfalfa were in bloom at the time, and varying amounts of hay alfalfa were blooming nearby. In 1954 and 1955 the colonies were moved to some seed acreage in Howell Valley, about 50 miles west of Logan.

\footnotetext{
1 Accepted for publication April 2, 1957.

2 In cooperation with Utah Agricultural Experiment Station.

The authors wish to express their appreciation to W. P. Nye for his help in carrying out some of the field work.
} 
Table 1.-Total pollen and alfalfa pollen collected per colony by three groups of colonies in 14 days at the Evans Farm, Logan, Utah. 1953.

\begin{tabular}{lcccc}
\hline \hline & & \multicolumn{2}{c}{ Alffalfa Pollen } \\
\cline { 3 - 4 } \multicolumn{1}{c}{ Group } & $\begin{array}{c}\text { Total } \\
\text { Pollen } \\
\text { (Grams) }\end{array}$ & Grams & $\begin{array}{c}\text { Per Cent } \\
\text { of Total }\end{array}$ \\
\hline Not moved & 427 & 1.5 & 0.35 \\
$\begin{array}{l}\text { Moved from other alfalfa } \\
\text { Moved from mountain loca- } \\
\text { tion }\end{array}$ & 782 & 4.3 & 0.55 \\
\hline
\end{tabular}

Here at least 200 acres of alfalfa in bloom were available to the bees.

There was one striking difference between the two areas. The Evans Farm was located in an area of diversified farming. There were various attractive nectar and pollen sources, such as mustard, clover, and sweetclover, as well as Russian-thistle, corn, and unidentified plants. In Howell Valley the sources of pollen and nectar were much more limited and probably less attractive. Aside from alfalfa, the major sources were saltgrass, gumweed, Russian-thistle, and thistle. Sweetclover was present in small amounts.

At the Evans Farm alfalfa-pollen collection was practically nil, rarely by more than $1 \%$ of the bees seen in the field. In the alfalfa fields at Howell the proportion of bees observed collecting pollen sometimes exceeded $50 \%$. Dif- ferent sources of pollen vary in their attractiveness to bees, as do pure pollens when isolated from the plant (Levin \& Bohart 1955). The greater proportion of pollen collectors at Howell can probably be ascribed to the less attractive complex of competing pollen sources. Apparently an equally important factor was the growing condition of the plants. Most of the alfalfa in seed fields at Howell appeared to be intrinsically attractive to pollen collectors.

Pollen Collection.-Data from the pollen-trap samples are presented in tables 1 and 2. The lower percentages of alfalfa-pollen collectors observed at the Evans Farm are reflected in the smaller percentages of alfalfa pollen in the traps.

The bees at Howell collected more pollen of all kinds in 1955 than in 1954. In both years both the total-pollen and the alfalfa-pollen collection tended to increase during the sampling period. The increase in amount of alfalfa pollen was maintained in spite of a decrease in the percentage. At the Evans Farm there were no consistent seasonal trends; alfalfa pollen was collected too sporadically and in too small quantities to warrant tabulation.

At both locations colonies moved from the mountains to the alfalfa fields collected about twice as high a percentage of alfalfa pollen (significant at the $1 \%$ level) as the other groups. At the Evans Farm, where these colonies collected more total pollen than either of the other groups, they also collected a significantly greater amount of alfalfa pollen. At Howell in 1954 the colonies

Table 2.-Total pollen and alfalfa pollen collected per colony by three groups of colonies in the Howell Valley, Utah. 1954 and 1955.

\begin{tabular}{|c|c|c|c|c|c|c|c|c|c|}
\hline \multirow[b]{2}{*}{ DAte } & \multicolumn{3}{|c|}{ Not Moved } & \multicolumn{3}{|c|}{ Moved from Other Alfalfa } & \multicolumn{3}{|c|}{ Moved from Mountain Location } \\
\hline & $\begin{array}{c}\text { Total } \\
\text { Pollen } \\
\text { (Grams) }\end{array}$ & $\begin{array}{l}\text { Alfalfa } \\
\text { Pollen } \\
\text { (Grams) }\end{array}$ & $\begin{array}{c}\text { Per Cent } \\
\text { of Alfalfa } \\
\text { Pollen }\end{array}$ & $\begin{array}{l}\text { Total } \\
\text { Pollen } \\
\text { (Grams) }\end{array}$ & $\begin{array}{c}\text { Alfalfa } \\
\text { Pollen } \\
\text { (Grams) }\end{array}$ & $\begin{array}{l}\text { Per Cent } \\
\text { of Alfalfa } \\
\text { Pollen }\end{array}$ & $\begin{array}{c}\text { Total } \\
\text { Pollen } \\
\text { (Grams) }\end{array}$ & $\begin{array}{l}\text { Alfalfa } \\
\text { Pollen } \\
\text { (Grams) }\end{array}$ & $\begin{array}{c}\text { Per Cent } \\
\text { of Alfalfa } \\
\text { Pollen }\end{array}$ \\
\hline $\begin{array}{r}1954 \text { July } 16 \\
17 \\
18 \\
19 \\
20 \\
21 \\
92 \\
23 \\
24\end{array}$ & $\begin{array}{l}1.43 \\
0.63 \\
1.0 \\
4.7 \\
8.96 \\
8.7 \\
8.7 \\
17.0 \\
96.9\end{array}$ & $\begin{array}{l}1.3 \\
0.4 \\
0.2 \\
0.5 \\
4.9 \\
0.5 \\
0.5 \\
1.9 \\
3.2\end{array}$ & $\begin{array}{r}89 \\
65 \\
21 \\
10 \\
55 \\
6 \\
6 \\
11 \\
12\end{array}$ & $\begin{array}{r}2.9 \\
3.5 \\
8.4 \\
13.1 \\
18.9 \\
11.8 \\
11.8 \\
13.6 \\
17.5\end{array}$ & $\begin{array}{l}1.2 \\
1.9 \\
1.8 \\
1.3 \\
3.4 \\
2.4 \\
2.4 \\
6.7 \\
5.0\end{array}$ & $\begin{array}{l}41 \\
54 \\
21 \\
10 \\
19 \\
20 \\
20 \\
49 \\
29\end{array}$ & $\begin{array}{r}7.4 \\
11.0 \\
5.0 \\
12.3 \\
22.3 \\
16.3 \\
16.3 \\
23.2 \\
14.7\end{array}$ & $\begin{array}{r}7.2 \\
10.6 \\
3.7 \\
5.0 \\
10.5 \\
7.9 \\
7.9 \\
13.7 \\
9.8\end{array}$ & $\begin{array}{l}97 \\
96 \\
74 \\
41 \\
47 \\
48 \\
48 \\
59 \\
67\end{array}$ \\
\hline Total or Average & 77.3 & 13.5 & 17.5 & 100.8 & 26.2 & 25.9 & 128.5 & 76.5 & 59.5 \\
\hline $\begin{array}{rr}1955 & \\
\text { July } & 29 \\
30 \\
31 \\
\text { Aug. } & 1 \\
2 \\
3 \\
4 \\
5 \\
6 \\
7 \\
8 \\
9 \\
10 \\
11 \\
12\end{array}$ & $\begin{array}{r}59 \\
28 \\
39 \\
64 \\
64 \\
78 \\
93 \\
89 \\
89 \\
116 \\
116 \\
102 \\
171 \\
73 \\
137\end{array}$ & $\begin{array}{r}4.2 \\
7.6 \\
14.0 \\
26.9 \\
26.9 \\
50.8 \\
65.2 \\
42.5 \\
42.5 \\
48.7 \\
55.3 \\
48.0 \\
75.7 \\
43.0 \\
84.5\end{array}$ & $\begin{array}{r}8 \\
27 \\
36 \\
42 \\
42 \\
65 \\
70 \\
48 \\
48 \\
42 \\
48 \\
47 \\
44 \\
59 \\
62\end{array}$ & $\begin{array}{r}0 \\
4 \\
4 \\
3 \\
3 \\
5 \\
7 \\
15 \\
15 \\
23 \\
22 \\
22 \\
42 \\
18 \\
29\end{array}$ & $\begin{array}{r}-\overline{4.0} \\
4.0 \\
2.9 \\
2.9 \\
5.0 \\
4.1 \\
5.5 \\
5.5 \\
7.5 \\
8.6 \\
7.6 \\
12.3 \\
7.2 \\
9.8\end{array}$ & $\begin{array}{r}100 \\
100 \\
97 \\
97 \\
100 \\
59 \\
37 \\
37 \\
33 \\
39 \\
34 \\
29 \\
40 \\
34\end{array}$ & $\begin{array}{r}7 \\
12 \\
15 \\
28 \\
28 \\
38 \\
40 \\
54 \\
54 \\
84 \\
74 \\
71 \\
107 \\
42 \\
82\end{array}$ & $\begin{array}{r}6.9 \\
12.0 \\
15.0 \\
25.5 \\
25.5 \\
36.8 \\
34.2 \\
41.9 \\
41.9 \\
65.9 \\
58.8 \\
57.6 \\
76.1 \\
33.9 \\
60.6\end{array}$ & $\begin{array}{r}99 \\
100 \\
100 \\
91 \\
91 \\
97 \\
86 \\
78 \\
78 \\
78 \\
79 \\
81 \\
71 \\
81 \\
74\end{array}$ \\
\hline Total or Average & 1309 & 635.6 & 48.6 & 212 & 86.9 & 40.9 & 736 & 592.6 & 80.5 \\
\hline
\end{tabular}


from the mountains also collected the most total pollen. Since the percentage of alfalfa pollen was greater for these colonies, the amount of alfalfa pollen was also significantly greater. In 1955 the colonies from the mountains collected more total pollen and far more alfalfa pollen than the ones from another alfalfa area (statistically significant at the $1 \%$ level), but only about half as much total pollen as those that had remained in the field. Consequently, they collected slightly less alfalfa pollen, even though the percentage was nearly twice as high.

Alfalfa Visitation BY Field Bees.-The results obtained from examining the field bees caught at the hive entrances are shown in table 3. At the Evans Farm in 1953, where alfalfa was a minor source of nectar, the percentage of field bees visiting alfalfa for either nectar or pollen was much lower than at Howell, where alfalfa predominated.

At the Evans Farm the colonies moved from an area where alfalfa predominated visited alfalfa the most freely, and the group longest in the field visited alfalfa the least. At Howell the colonies longest in the field also tended to be lowest in alfalfa visitation. The colonies from the mountains showed the highest alfalfa visitation in $\mathbf{1 9 5 4}$, but only about the same as the ones from another alfalfa area in 1955 .

At the Evans Farm visitation to alfalfa by all groups of colonies tended to increase as the sampling period progressed. At Howell alfalfa visitation by the groups that had remained in the field stayed about the same, but for the other groups it showed a progressive decline in

Table 3.-Per cent of field bees visiting alfalfa.

\begin{tabular}{|c|c|c|c|}
\hline \multirow[b]{2}{*}{ Date } & \multirow[b]{2}{*}{$\begin{array}{c}\text { Not } \\
\text { Moved }\end{array}$} & \multicolumn{2}{|c|}{ Moved FROM } \\
\hline & & $\begin{array}{c}\text { Other } \\
\text { Alfalfa }\end{array}$ & $\begin{array}{l}\text { Mountain } \\
\text { Location }\end{array}$ \\
\hline & & Evans Farm & \\
\hline \multicolumn{4}{|l|}{1953} \\
\hline $\begin{array}{r}\text { July } 18 \\
19\end{array}$ & 0.7 & $\begin{array}{l}9.5 \\
9.9\end{array}$ & $\begin{array}{l}3.2 \\
2.5\end{array}$ \\
\hline $\begin{array}{l}19 \\
20\end{array}$ & 1.6 & 19.6 & $\begin{array}{l}2.5 \\
2.4\end{array}$ \\
\hline 21 & 6.1 & 49.0 & 5.4 \\
\hline 22 & 5.8 & 23.6 & 6.2 \\
\hline 23 & 4.6 & 34.6 & 10.5 \\
\hline 24 & 3.1 & 21.1 & 8.3 \\
\hline 25 & 6.3 & 36.9 & 8.2 \\
\hline 27 & 8.7 & 41.7 & 12.1 \\
\hline Average & 4.5 & 27.7 & 7.0 \\
\hline & & Howell Valley & \\
\hline \multicolumn{4}{|c|}{ - } \\
\hline July 16 & - & 62.3 & 74.8 \\
\hline 17 & 43.6 & 36.0 & 58.7 \\
\hline 19 & 29.4 & 23.0 & 55.8 \\
\hline 20 & 47.1 & 34.9 & 57.1 \\
\hline 22 & 39.8 & 37.2 & 44.2 \\
\hline 23 & 39.7 & 27.3 & 32.3 \\
\hline Average & 39.9 & 36.8 & 53.8 \\
\hline \multicolumn{4}{|l|}{1955} \\
\hline July $\mathbf{3 0}$ & 39.8 & 67.2 & 68.9 \\
\hline 31 & 39.0 & 55.1 & 62.4 \\
\hline Aug. 2 & 36.8 & 51.0 & 51.1 \\
\hline 3 & 51.4 & 65.4 & 54.7 \\
\hline 4 & 51.6 & 45.6 & 46.8 \\
\hline 7 & 34.3 & 28.8 & 27.8 \\
\hline Average & 42.2 & 52.2 & 51.9 \\
\hline
\end{tabular}

both years. By the end of the sampling periods the groups moved in were visiting alfalfa to a lesser degree than the ones that had remained there. However, none of these trends were statistically significant.

Brood and Pollen Measurements in 1955.-Four colonies from the stationary group averaged 239 square inches of pollen and 844 square inches of brood. Five colonies in the group from another alfalfa field had 395 square inches of pollen and 813 square inches of brood, while five colonies in the mountain group averaged 478 square inches of pollen and 1075 square inches of brood. The stationary group had $28 \%$ as much pollen as brood, while the other two groups averaged 48 and $44 \%$ as much pollen as brood, respectively.

Discussion.- The data for the three seasons show that bees with no previous experience with alfalfa tend to collect a higher percentage of alfalfa pollen than colonies with such experience. This could be of considerable importance if the immigrant colonies always collected as much total pollen as the ones already accustomed to the area. Two seasons out of three this was true. However, in 1955 the stationary colonies, because of their high totalpollen intake, ended the sampling period with slightly more alfalfa pollen than the immigrants from the mountains.

The explanation for the differences between groups in total pollen collected is not known, but at Howell in 1955 there was evidence that colony condition, as indicated by amounts of brood and pollen in the combs, might have been partly responsible. While the amounts of pollen collected by the three groups were in accordance with their need, as expressed in the proportion of pollen to brood, the differences in pollen reserves hardly seem large enough to account for the great inequality in amount of pollen collected. Farrar (personal communication) reports that his observations do not show any correlation between pollen reserves and pollen collection. There is need for more investigations on factors within the hive that influence pollen collection.

As expected, the colonies moved from the mountains to the seed fields at Howell collected alfalfa pollen almost exclusively for a few days and then began to range more widely. Although the percentage of alfalfa pollen collected dropped off as a result, it didn't fall to the levels maintained by the other groups. Furthermore, because of a general rising trend in pollen collection, the total amount of alfalfa pollen collected actually increased during the sampling period.

The above trends reflect the generally increasing amount of bloom observed in the Howell Valley during late July and early August. This was even more noticeable for competing pollen sources than for alfalfa. The remarkable fact is that more bees began to collect alfalfa pollen in the face of increasing competition from other sources. The same phenomenon has been observed at Fielding and Newton, Utah. It appears that fluctuations in abundance of competing sources have little effect on alfalfa-pollen collection, except when the competing sources are extremely scarce.

The information obtained from field bees collected at the entrances indicates that the percentage of bees visiting a crop-at least for nectar-is roughly equivalent to the percentage that the crop comprises of the total 
attractive bloom in the area. In Howell Valley, in both 1954 and 1955 , about $45 \%$ of the field bees were working alfalfa, whereas on the Evans Farm in 1953 this figure was only about $13 \%$. The proportion of alfalfa acreage in bloom in these two areas differed by about the same degree.

Under the conditions of more diversified flora at the Evans Farm, the stationary colonies were largely oriented to sources of nectar and pollen other than alfalfa. The bees moved into this diversified flora from an area where alfalfa was predominant carried with them their orientation to alfalfa for nectar. At Howell, where alfalfa predominated, all groups of colonies established and maintained a strong orientation to alfalfa. It appears, then, that moving colonies from one alfalfa field to another would be of special benefit to the second field only if alfalfa bloom was a major source in the neighborhood of the first field and a minor source near the second.

Summary.-Experiments to determine the effect of prior experience with alfalfa on the activities of colonies of honey bees, Apis mellifera L., in an alfalfa field were conducted near Logan and Howell, Utah, in 1953, 1954, and 1955. Each year samples from pollen traps and from entrance-caught field bees were collected from three groups of colonies. One group had been in the alfalfa field from the beginning of alfalfa bloom in the area, the second had been moved in from another alfalfa field, and the third had been in an alfalfa-free mountain location for at least a month.

In all three years the colonies from the alfalfa-free mountain location collected about twice as high a percentage of alfalfa pollen as the other groups. In 2 years they also collected greater quantities of all pollen and alfalfa pollen. In the third year they collected less than half as much total pollen and a slightly smaller amount of alfalfa pollen than the group that had remained in the field.

The percentage of entrance-caught field bees working alfalfa was roughly equivalent to the percentage of alfalfa bloom in the area.

Results of these experiments indicate that moving colonies from one alfalfa field to another will be of special benefit only when the move is made from an area where alfalfa is predominant to an area where alfalfa comprises only a small part of the bee pasturage.

\section{References Cited}

Levin, M. D. 1955. A technique for estimating the percentage of honey bees visiting alfalfa. Jour. Econ. Ent. 48: 484-5.

Levin, M. D., and G. E. Bohart. 1955. Selection of pollen by honey bees. Amer. Bee Jour. 95: 392, 402.

Vansell, G. H. 1955. Alfalfa pollen on nectar-collecting honey bees. Jour. Econ. Ent. 48: 477 .

\section{Reprinted from the}

JoURNAL of ECONOMIC ENTOMOLOGY

Vol. 50, No. 5, pp. 629-632, October 1957 